\title{
Statistical estimation of frictional coefficients of faults based on a structural dataset in the Tuy Hoa-Vung Tau Region, Viet Nam
}

\author{
Do Van Linh ${ }^{1}$, Nguyen Loi Loc ${ }^{1,3,6}$, Vu Trong Tan ${ }^{1}$, Nguyen Xuan Huy ${ }^{2,3, *}$, Nguyen Thi Thu Trang ${ }^{2,3}$, \\ Pham Huu Tai ${ }^{2,3,4}$, Muslim Abdurrahman ${ }^{5}$, and Fiki Hidayat ${ }^{5}$ \\ ${ }^{1}$ South-Vietnam Geological Mapping Division, 200 Ly Chinh Thang Street, Ward 9, District 3, Ho Chi Minh City 700000 , Vietnam \\ ${ }^{2}$ Faculty of Geology and Petroleum Engineering, Ho Chi Minh University of Technology (HCMUT), 268 Ly Thuong Kiet Street, \\ District 10, Ho Chi Minh City 700000, Vietnam \\ ${ }^{3}$ Vietnam National University Ho Chi Minh City, Linh Trung Ward, Thu Duc District, Ho Chi Minh City 700000 , Vietnam \\ ${ }^{4}$ PetroVietnam University, 762 Cach Mang Thang Tam Street, Long Toan Ward, Ba Ria City, Ba Ria - Vung Tau Province 790000 , \\ Vietnam \\ ${ }^{5}$ Department of Petroleum Engineering, Universitas Islam Riau, Jl. Kaharuddin Nasution 113, Pekanbaru Riau 28284, Indonesia \\ ${ }^{6}$ Faculty of Geology, University of Science, 227 Nguyen Van Cu Street, District 5, Ho Chi Minh City, 700000, Vietnam
}

Received: 19 November 2020 / Accepted: 18 March 2021

\begin{abstract}
This study estimates the shear friction coefficient from shear friction angles for the prediction of slip tendencies in the Tuy Hoa-Vung Tau region of Southern Vietnam. A dataset consisting of measured data of 355 fractured planes, striations, and unconformities in coastal areas as well as 239 offshore faults was analyzed based on the principles of statistical probability. As a result, 138 friction angles for the onshore and offshore faults were calculated based on shear fracture conjugate pairs. The goodness-of-fit test was used to define the probability distribution of the friction angles, which had a normal distribution. The acceptable average of friction angles for the onshore region with a reliability of more than $95 \%$ were in the range of $25.8^{-}-31.5^{\circ}$, which corresponds to frictional coefficients of $0.48-0.61$. The acceptable average friction angles for the offshore region were relatively low at $23-31^{\circ}$, which corresponds to a frictional coefficient of $0.42-0.60$. Owing to the heterogeneity of the fault system, the median value $\left(19.12^{\circ}\right)$ should be used as the lowest threshold value for slipping faults at all conditions. The recommended applicable average friction angles are $28.65^{\circ}$ and $27^{\circ}$ for the onshore and offshore regions, respectively. The estimation of the frictional coefficients is highly reliable, and it can be applied to other subsurface resource exploitation projects within the study area.
\end{abstract}

\section{Introduction}

In the process of geological mapping and mineral exploration, the identification of striations in the dip direction and dip angle of the fault, which can lead to slip or overturn, is essential for determining the slip friction angle and the cohesion of the fault. Through field investigations, information can be gathered on fracture surface properties, including the continuity of length, surface roughness, width and depth, secondary mineral characteristics in the fracture, and the influence of water on mineral deposits [1].

The coefficient of friction, $\mu$, is a characteristic of the first-order functional friction. The coefficient of static friction is also known as the coefficient of internal friction, basic friction, or residual friction. It is an essential parameter that

\footnotetext{
* Corresponding author: nxhuy@hcmut.edu.vn
}

controls fault motion but it is not related to stick-slip behavior. The coefficients of static friction $\left(\mu_{s}\right)$ and kinetic friction $\left(\mu_{k}\right)$ depend on the nature of the component surface of the contact rock (Fig. 1). The value of the coefficient of shear friction is less than that of static friction $\left(\mu_{k}<\mu_{s}\right)$. While performing stability analyses, crustal rocks are often assumed to act as a Mohr-Coulomb material in its response to shear stress, whereby its shear strength is expressed in terms of the cohesion and angle of the slickenlines [2]. Tectonic stress can cause large earthquakes and crustal faults to weaken or slide steadily. Byerlee's frictional coefficient $(0.6<\mu<0.85)$ is widely applied to the naturally sliding plane of a fault [3], which can extend several kilometers in depth through the upper crust, from Earth's surface toward the point of origin of an earthquake.

The shear strength of a flat, clean fracture with no scratches and an adhesive force of zero can be determined 


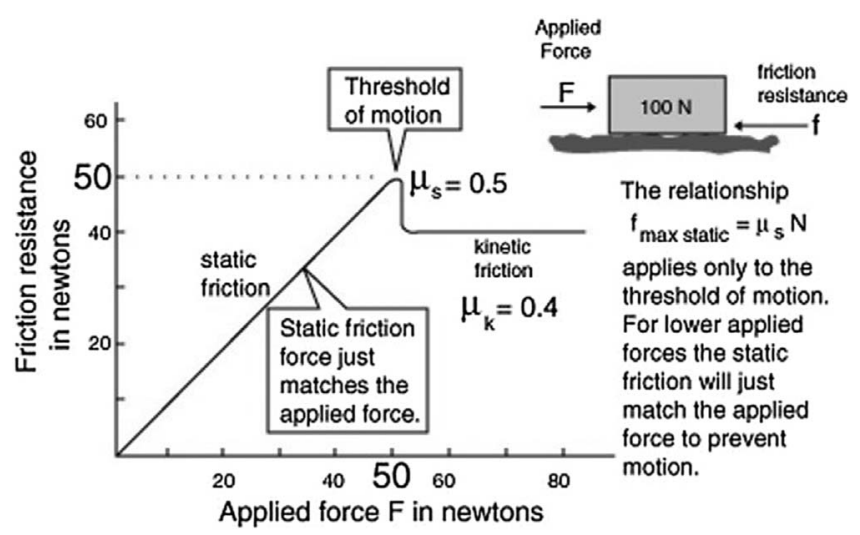

Fig. 1. Static and kinetic friction.

using the static friction angle. The friction angle of the rock material is related to the size, shape, and composition of the particles exposed along the fault surface. Therefore, a finegrained rock with a high mica content will have a small friction angle while a coarse-grained rock will have a large friction angle. The measured friction angles in sedimentary rocks range from $25^{\circ}$ to $30^{\circ}$, while in intrusive and metamorphic rocks, they range from $30^{\circ}$ to $35^{\circ}$. Table 1 lists the friction angle values of each rock type [4, 5].

Yukutake et al. [6] identified that accurately estimating the slip friction coefficient of a fault to evaluate the slip tendency using the frictional resistance of a fault is difficult. They determined the slip friction coefficient by analyzing the conjugate angles of faults based on the focal mechanisms of dip-slip earthquakes. Instead, they applied the coefficient of friction, according to [3] friction law. However, the results were not convincing when applied to specific areas to estimate slip tendencies and design water injection pressure thresholds. Thus, this method cannot be used in regions with different tectonic and petrological conditions.

At conditions with soft soil and pre-existing fault zones, reactivated faults exhibit a low frictional coefficient of $\sim 0.3$ or even 0.1 , as observed from dip-slip earthquake focal mechanisms [7]. The frictional reactivation angle for faults in coal mines ranges from $8^{\circ}$ to $18^{\circ}$, [8]. Tamura and Kambayashi [9] presented a fault analysis to estimate the frictional coefficient.

The tilt and direct shear tests are standard methods used to determine the friction angle [10-12]. In terms of geological form, e.g., in a heterogeneous and discontinuous granite in Bukit Pengorak (Malaysia), the basic friction angle of granite was determined to be $30^{\circ}$ and the maximum friction angle changed from $47^{\circ}$ to $80^{\circ}$, depending on the roughness of the surface [13].

Furthermore, the coefficient of shear friction depends on many factors, such as the filling material, degree of mineral variation, hydrothermal activity, and orientation of fracture relative to the modern stress field. A study on the Alpine Fault in New Zealand estimated the shear frictional coefficient to be $0.12-0.16$ at temperatures from $25{ }^{\circ} \mathrm{C}$ to $210{ }^{\circ} \mathrm{C}$, corresponding to an effective normal stress $\left(\sigma_{n}^{\prime}\right)$ of 31.2-93.6 MPa. Boulton et al. [14] showed that spaces between the fault planes were filled with clay particles, which significantly affected the shear friction.
Table 1. Classification of the friction angle by rock composition.

\begin{tabular}{lcl}
\hline Classification $\begin{array}{c}\text { Friction angle } \\
\text { (degree) }\end{array}$ & \multicolumn{1}{c}{ Type of rock } \\
\hline Low & $20-27$ & Schists (mica), clay, marl \\
Medium & $27-34$ & $\begin{array}{l}\text { Sandstone, siltstone, chalk, } \\
\text { gneiss, slate }\end{array}$ \\
High & $34-40$ & $\begin{array}{l}\text { Basalt, granite, limestone, } \\
\text { conglomerate }\end{array}$ \\
& &
\end{tabular}

Jeanne et al. [15] examined the distribution law of the friction coefficient. They applied the law of friction to evaluate the effect of fracture stability based on seismic data collected during carbon capture and storage. Simulation results showed that the distribution of the static and dynamic frictional coefficients (before failure) varied along the fault, with intensities of $1.88-5.88$. The critical values of the frictional coefficients (minimum and maximum) along the fault zone could be predicted to control the degree of stress intensity accumulation before failure.

Assuming that the tectonic stress field and fault direction are stable, the shear stress on a fault plane $(i)$ will not change at a particular moment for at least thousands of years. Therefore, faults slip when the friction angle exceeds the internal friction angle. In principle, the coefficient of shear friction is relatively stable because it reflects the inherent nature of the fault. Thus, we must consider the effect of stress to investigate fault reactivation.

A pioneering method proposed by Anderson [16] to determine the paleostress direction assumes that conjugate pairs of shear fractures evolved according to the MohrCoulomb standard. Pairs of conjugate fractures are two fault planes or microscopic fractures that are generated simultaneously in the newly formed structure. The dihedral angles between the two fault planes vary from $30^{\circ}$ to $89^{\circ}$ for brittle deformation and are $>90^{\circ}$ for ductile deformation. Depending on the nature of the mechanical and physical properties of the brittle deformation, i.e., brittle-ductile or ductile, this angle varies from $30^{\circ}$ to $150^{\circ}$. Usually, this dihedral angle in brittle granite ranges from $55^{\circ}$ to $62^{\circ}$ and can sometimes be close to $90^{\circ}$. When the friction angle is more extensive, this corresponding angle approaches $90^{\circ}$. The conjugate fracture pairs determined using statistical analyses of the outcrop in this study exhibit shear and normal stresses at a point on the largest Mohr circle.

Assumptions of shear friction angles with different values can lead to errors in the design of drilling wells or when determining the water injection volume threshold for oil recovery. For instance, in the White Tiger oil field, offshore Vietnam, the shear friction angles of two wells (A and B) in a fractured granite reservoir changed from $48^{\circ}$ to $57^{\circ}$ at depths from 4000-4300 m [17]. While examining the stress state of the oil and gas fields in the Cuu Long and Nam Con Son basins, Binh et al. [18] estimated that the frictional coefficient of a strike-slip normal fault in the basin was $\sim 0.5$, which corresponds to a shear friction angle of $26.6^{\circ}$. The lower threshold of the shear friction angle was also set at $16.7^{\circ}$ for analysis using the TENSOR program. Thus, 
the accuracy of the shear friction angle is essential for forecasting the slip tendency and rock stability.

Based on a study of geothermal energy production, Gan and Elsworth [19] suggested that injecting fluid into a reservoir at high temperatures increased the pore-pressure and widened fracture apertures to facilitate fault motion, causing subterranean fault reactivation. Therefore, frictional properties influence the instability of faults and associated seismic events.

The internal friction angle depends on the rock type, porosity, and bonding. The weaker the rock, the lower the shear friction angle. Lama and Vutukuri [20] found that higher Young's elastic modulus values of the rock result in higher shear friction angles. Son et al. [21] calculated the shear friction angle in the Oligocene sandstone reservoir $(4012-4077 \mathrm{~m})$ of the White Tiger oil field to be $28^{\circ}-45^{\circ}$ based on Poisson's coefficient and the geophysical log $V_{p} / V_{s}$ curve obtained from the well.

Sato [22] used a numerical method to estimate the slip friction coefficient based on the statistical probability distribution theory of points on the Mohr circle. The standard Mohr circle, where $\sigma_{3}=0, \sigma_{1}=1$, and $\sigma_{2}=$ the stress ratio (from the inversion of striations or earthquake focal mechanisms), was used to obtain the shear and normal stresses along the sliding fault plane for any direction and dip angle in space within a specific tectonic stress field [23, 24]. Sato [22] argued that the points on a Mohr circle represent a density probability distribution close to the Mohr circle, which declines in the direction of the stress vector. Furthermore, by statistically obtaining the decrease in the vector direction, the slip friction coefficient can be calculated.

Energy projects are currently being developed in Tuy Hoa-Vung Tau region, wherein geothermal exploitation, oil and gas field exploitation, underground storage, and dam construction for hydroelectric power will be conducted in onshore and offshore regions. Thus, determining the shear friction coefficient thresholds from the shear friction angles is vital for predicting the slip tendencies, which can identify the impact of human activity or natural disasters. At present, no study has calculated the coefficients of friction in this region; instead, most studies use the assumed values of [3] or similar rock compositions from previous studies. The shear friction coefficient threshold is a primary parameter that can be used to assist managers in decisionmaking regarding the pre-feasibility and operational stages, as well as reducing costs by forecasting and minimizing risk. Human activity can change the stress balance and cause faults to slide or reactivate, thereby increasing the reservoir interconnections and enabling efficient resource exploitation.

\section{Geological setting}

The Tuy Hoa-Vung Tau region includes a territory in south-central Vietnam (Fig. 2) and its continental shelf, and is located in the western South China Sea (center of the Southeast Asian plate). This area is likely to have formed and developed on the Precambrian crystalline basement, followed by the development of an active continental margin setting during the late Mesozoic. The region was influenced by extension and lateral strike-slip movement in the early Cenozoic, followed by domain uplift with basalt volcanism during the late Cenozoic. From a modern tectonic perspective, the study region includes continental crust structural units (i.e., the Kon Tum, Da Lat, and Can Tho zones) as well as extensional, thinned, and differentiated transitional crust forming numerous oil-bearing Cenozoic basins.

From the Paleoproterozoic to the Quaternary, the study area experienced at least 14 other geodynamic settings, which can be reconstructed by their characteristic petrotectonic assemblages and are outlined in Table 2. The study area is located between three features (Fig. 2): the Indochina continental crust, Cuu Long-Con Son structural domain, and Paracel Islands-Borneo continentaltransitional crust terrane.

In the early Cenozoic, the study area formed part of the southeastern interior of the Eurasian plate, which was influenced by two significant dynamic processes:

1. collision between India and Asia in the west, where the northwest-striking Mae Ping and Three Pagodas faults cut through the northwestern part of Indochina; and

2. the Red River fault, oriented in a northeast-southeast direction and the South China Sea divergent processes, which began in the Late Cretaceous [25, 26] and continued to spread at a maximum of $32-$ 16 Ma, creating the new South China Sea oceanic plate [27].

The study area is a part of Indochina where basaltic eruption was accompanied by intensive massif uplift since the late Cenozoic. Here, extensional activity, sliding, and thermal subsidence meet a transitional continental crust massif. The formation mechanism resulted in two primary structural parts:

1. pre-Cenozoic crystallized basement, consisting of plutonic, volcanic, and sedimentary rocks and constituting the Indochina continental block; and

2. an overburden layer, consisting of mainly late Cenozoic terrestrial clastic sediment, interbedded with basalt rock, which filled in the Phu Khanh and Cuu Long basins, forming part of the transitional continental crust.

The coastal area from Tuy Hoa developed 21 major fault systems, including four faults at level I, seven faults at level II, and ten faults at level III. The faults are developed in four main directions: NW-SE, NE-SW, E-W, or sub-E-W, and N-S or sub-N-S (Tab. 3).

Unconformable contacts are generally referred to as unconformities (Tab. 4).

The Cenozoic tectonic evolution in the study area and adjacent areas includes three main periods with six subperiods (Tab. 5).

The compressive axis of the tectonic stress field construction has not changed substantially from the late 




Fig. 2. Map of the geoblock, stress field, and human impacts on the environment.

Miocene to Quaternary, although it is different from the previous period in the geodynamic regime (i.e., the early to middle Miocene, when compression occurred in a
NEN-SWS direction, and from the middle Eocene to early sub-Miocene, when compression was toward the sub-latitudes). 
Table 2. Geodynamic settings.

\begin{tabular}{|c|c|c|c|}
\hline No & Time period & Tectonic setting & Characteristic assemblages \\
\hline 1 & Paleoproterozoic & Unknown & Gneiss, amphibolite, crystallized schists \\
\hline 2 & Cambrian & Passive continental margin & Quartzite, quartz-sericite schist, greenschist \\
\hline 3 & Silurian & Active margin subduction & $\begin{array}{l}\text { (Hornblende-biotite gneiss-granodiorite, gneiss- } \\
\text { diorite) }\end{array}$ \\
\hline 4 & Devonian & Plate collision & Gneissoid two-mica granite, biotite granite \\
\hline 5 & Late Paleozoic & Active continental margin & (Diorite, granodiorite, granite) \\
\hline 6 & $\begin{array}{l}\text { Early-Middle } \\
\text { Triassic }\end{array}$ & Plate collision & Biotite granite, two-mica granite \\
\hline 7 & Middle Triassic & Post-collision rifting & Dacite, rhyolite, tuff; granite, granosyenite \\
\hline 8 & $\begin{array}{l}\text { Early-Middle } \\
\text { Jurassic }\end{array}$ & Post-collision intraplate basin & Sandstone, siltstone, argillaceous limestone \\
\hline 9 & Cretaceous & Active continental margin subduction & Dacite, rhyolite; granitoid, granite \\
\hline 10 & Late Cretaceous & $\begin{array}{l}\text { Rifting of the upper and } \\
\text { magmatic back arc }\end{array}$ & $\begin{array}{l}\text { Dacite, felsite, rhyolite, andesite, tuff; biotite granite, } \\
\text { two-mica granite }\end{array}$ \\
\hline 11 & $\begin{array}{l}\text { Middle Eocene-- } \\
\text { Oligocene }\end{array}$ & Rifting or pull-apart basin & $\begin{array}{l}\text { Conglomerate, silty sandstone, silty sandstone, } \\
\text { oil-bearing shale }\end{array}$ \\
\hline 12 & $\begin{array}{l}\text { early-middle } \\
\text { Miocene }\end{array}$ & Thermal subsidence or post-rifting & $\begin{array}{l}\text { Conglomerate, gravestone, gritstone, sandstone, } \\
\text { siltstone, claystone }\end{array}$ \\
\hline 13 & $\begin{array}{l}\text { Late Miocene- } \\
\text { Quaternary }\end{array}$ & $\begin{array}{l}\text { Flood basalt and block doming mixed } \\
\text { with inversion, strike-slip faulting, } \\
\text { or tectonic extrusion }\end{array}$ & $\begin{array}{l}\text { Tholeiitic basalt, sub alkaline, basalt, andesite- } \\
\text { basalt, marine sediment }\end{array}$ \\
\hline 14 & $\begin{array}{l}\text { Pliocene- } \\
\text { Quaternary }\end{array}$ & East Vietnam continental shelf & $\begin{array}{l}\text { Fluvial-proluvial, fluvial sediments, pebbles, } \\
\text { boulders, fluvio-marine sediment, sand, silt, grey clay } \\
\text { containing forams, red sand. }\end{array}$ \\
\hline
\end{tabular}

\section{Data and methods}

\subsection{Geological field techniques (Measuring fault slip and estimating friction angle at outcrops)}

Measurements were taken of fractured planes, striations, and unconformities in outcrops of the Late Cretaceous granite in the Deo Ca complex, the late Miocene Basalt in the Dai Nga complex, and the Cretaceous rhyolites in the Nha Trang complex along the coastal areas from Tuy Hoa, Ke Ga, and Vung Tau to Phu Quy Island. A geocompass and measuring tape were used to determine the morphology and scale of the features according to the following procedure:

1. measure the strike of fractures containing striations;

2. measure the dip direction and dip of the fractures or microfaults;

3. determine and measure the plunge and trend of the slip vector on the microfault surface;
4. determine the movement sense of the microfault or use indicators [28] (i.e., record the kinematic type as strike-slip, normal, reverse fault, etc.);

5. measure the rake angle or pitch of the microfault using the geo-compass or a degree ruler;

6. observe and find the angle of the conjugate fault system, which can be identified by the direction of the sliding pinch on the intersection point between two faults (this angle is twice the friction angle of the fault slip); and

7. record all measurements in a geological notebook.

\subsection{Data processing}

The data collected from the steps described in the previous section were processed as follows:

1. the recorded data was processed to define the stress tensor at an exposed outcrop (from several hundred 
Table 3. Morphological and dynamic characteristics of major faults in the coastal area from Tuy Hoa to Vung Tau.

\begin{tabular}{|c|c|c|c|c|c|c|}
\hline No & Fault name & Strike & Dip direction/Dip & Length $(\mathrm{km})$ & Width, depth $(\mathrm{km})$ & Regime N2-Q \\
\hline & Fault ranking $I$ & & & & & \\
\hline 1 & Vung Tau-Ca Na & NE-SW & $\mathrm{SE} / 70-75^{\circ}$ & $>230$ & $60, \mathrm{XV}$ & LS-NF \\
\hline 2 & 109 (Eastern Viet Nam) & $\mathrm{N}-\mathrm{S}$ & $\mathrm{NE} / 62-85^{\circ}$ & $>290$ & $30, \mathrm{XV}$ & LS-NF \\
\hline 3 & Dong Phu Quy & NE-SW & $\mathrm{NE} / 46-78^{\circ}$ & $>325$ & $30, \mathrm{XV}$ & $\mathrm{S}-\mathrm{NF}$ \\
\hline 4 & Tay Phu Quy & NE-SW & $\mathrm{NW} / 70-81^{\circ}$ & $>340$ & $30, \mathrm{XV}$ & $\mathrm{S}-\mathrm{NF}$ \\
\hline & Fault ranking II & & & & & \\
\hline 5 & Vam Co Dong River & NW-SE & $\mathrm{SW} / 75-80^{\circ}$ & $>200$ & $30, \mathrm{XV}$ & RS-NF \\
\hline 6 & Sai Gon River & NW-SE & $\mathrm{SW} / 70-80^{\circ}$ & $>220$ & $30, \mathrm{XV}$ & RS-NF \\
\hline 7 & Binh Long - Binh Chau & NW-SE & $\mathrm{SW} / 70-75^{\circ}$ & $>192$ & $30, \mathrm{XV}$ & RS-NF \\
\hline 8 & Hon Hai & NE-SW & $\mathrm{SE} / 51^{\circ}$ & $>145$ & $20, \mathrm{~V}$ & NF-RS \\
\hline 9 & Dong Nam Hon Hai & NE-SW & $\mathrm{SE} / 26^{\circ}$ & $>160$ & $?$ & $\mathrm{NF}$ \\
\hline 10 & Ba River & NW-SE & $\mathrm{NE} / 70-84^{\circ}$ & 250 & $35, \mathrm{XV}$ & RS-NF \\
\hline 11 & Tuy Hoa - Bien Hoa & NE-SW & $\mathrm{NW} / 60-75^{\circ}$ & $\sim 365$ & $30, \mathrm{XV}$ & LS-NF \\
\hline & Fault ranking III & & & & & \\
\hline 12 & Da Nhim - Nha Trang & NE-SW & $\mathrm{NW} / 65-70^{\circ}$ & 200 & $25, \mathrm{~V}$ & LS-NF \\
\hline 13 & Long Hai - Tuy Phong & NE-SW & $\mathrm{SE} / 70-75^{\circ}$ & $<295$ & $20, \mathrm{~V}$ & LS-NF \\
\hline 14 & Ba To - Cung Son & Sub N-S & $\mathrm{E} / 70-80^{\circ}$ & $>110 \mathrm{~km}$ & $30, \mathrm{XV}$ & LS-NF \\
\hline 15 & Loc Ninh - Go Cong & $\mathrm{N}-\mathrm{S}$ & $\mathrm{W} / 70-80^{\circ}$ & $>250$ & $25, \mathrm{~V}$ & LS-NF \\
\hline 16 & Ca Nui River & NW-SE & $\mathrm{NE}$ & $>55$ & $?$ & RS-NF \\
\hline 17 & Tay Nui chua & Sub N-S & $\mathrm{E}-\mathrm{NE}$ & $>85$ & $?$ & $?$ \\
\hline 18 & $\mathrm{Ke} \mathrm{Ga}$ & NE-SW & $\mathrm{SE} / 66^{\circ}$ & $>160$ & $?$ & LS-NF \\
\hline 19 & Dong Bach Ho & NE-SW & $\mathrm{SE} / 66^{\circ}$ & $>175$ & $?$ & RS-NF \\
\hline 20 & Tay Bach Ho & NE-SW & $\mathrm{SE} / 58^{\circ}$ & $>178$ & $?$ & LS-NF \\
\hline 21 & Phu Quy & NE-SW & E-SE & $>170$ & $?$ & $\mathrm{~S}-\mathrm{NF}$ \\
\hline
\end{tabular}

** LS-NF: Normal left strike-slip faulting: RS-NF: Normal right strike-slip faulting; NF: Normal faulting; S-NF: Normal strike-slip faulting; NF: Normal faulting; and ?: Unknown.

Table 4. Unconformities.

\begin{tabular}{ll}
\hline Geologic contact & \multicolumn{1}{c}{ Time period } \\
\hline Three regional & Late Cretaceous to early \\
unconformities & Paleocene \\
& Middle Eocene to late Eocene \\
& Early Miocene to middle \\
& Miocene \\
Six local unconformities & Late Eocene to early Oligocene \\
& Late Oligocene to early Miocene \\
& Middle Miocene to early \\
& Miocene \\
& Late Miocene to early Pliocene \\
& Late Pliocene to early \\
& Pleistocene \\
& Late Pleistocene to middle \\
& Pleistocene
\end{tabular}

to thousands of meters in length), which has at least four microfaults measured that are distinct in orientation in the same rock type (e.g., granite, gabbro, sandstone, basalt, etc.);

2. the Win-Tensor [29] software was used to separate the structures into different stress tensors or different stress states based on the population of striations and slickenlines. The reduced stress tensor, corresponding to every sub-set microfault, was determined and categorized using four parameters: the stress ratio $(\phi)$ and the orientations (trend/plunge) of the three principal stress axes (largest, smallest, and intermediate);

3. MohrPlotter 3D [30] was used to analyze striations and slickenlines under the stress tensor that governed them, with a normalized tensor of $\sigma_{1}=1, \sigma_{2}=\phi$, and $\sigma_{3}=0$, and to determine the shear stress and normal stress on each microfault at any orientation; and

4. the angle of the set of faults (represented by a cluster of small circles) was then measured to calculate the 
Table 5. History of the Cenozoic tectonic evolution.

\begin{tabular}{|c|c|c|c|c|c|}
\hline \multirow[t]{2}{*}{ Time period } & \multirow[t]{2}{*}{ Sub-periods } & \multirow[t]{2}{*}{ Tectonic regime } & \multicolumn{3}{|c|}{ Principle stress } \\
\hline & & & $\begin{array}{c}\text { Maximum } \\
\text { compressive } \\
\text { stress axis }\left(\sigma_{1}\right)\end{array}$ & $\begin{array}{l}\text { Intermediate } \\
\text { compressive } \\
\text { stress axis }\left(\sigma_{2}\right)\end{array}$ & $\begin{array}{c}\text { Minimum } \\
\text { compressive } \\
\text { stress axis }\left(\sigma_{3}\right)\end{array}$ \\
\hline $\begin{array}{l}\text { Paleocene to middle } \\
\text { Eocene (S1) }\end{array}$ & & & Vertical & NNE-SSW & WNW-ESE \\
\hline \multirow[t]{3}{*}{$\begin{array}{l}\text { Middle-late Eocene } \\
\text { to early Miocene (S2) }\end{array}$} & $\begin{array}{l}\text { Middle Eocene to } \\
\text { late Eocene (S2.1) }\end{array}$ & & Vertical & ENE-WSW & NNW-SSE \\
\hline & Oligocene (S2.2) & Strike-slip & Sub-E-W & Vertical & Sub-N-S \\
\hline & $\begin{array}{l}\text { Early Miocene } \\
(\mathrm{S} 2.3)\end{array}$ & Strike-slip & NE-SW & Vertical & NW-SE \\
\hline \multirow[t]{3}{*}{$\begin{array}{l}\text { Middle Miocene-- } \\
\text { Quaternary (S3) }\end{array}$} & $\begin{array}{l}\text { Middle Miocene to } \\
\text { late Miocene (S3.1) }\end{array}$ & $\begin{array}{l}\text { Shallow plunge } \\
\text { angle }\end{array}$ & NNW-SSE & Vertical & ENE-WSW \\
\hline & $\begin{array}{l}\text { Pliocene to early } \\
\text { Pleistocene (S3.2) }\end{array}$ & & $\begin{array}{l}\text { Sub-N-S } \\
\text { direction }\end{array}$ & Vertical & sub-E-W \\
\hline & $\begin{array}{l}\text { Middle-late } \\
\text { Pleistocene to } \\
\text { Holocene (S3.3) }\end{array}$ & & $\begin{array}{l}\text { NNW-SSE (low } \\
\text { plunge angle) }\end{array}$ & Sub-vertical & ENE-WSW \\
\hline
\end{tabular}

friction angle by measuring from the origin coordinates of the Mohr circle (see [22]). An error of $\sim 6 \%$ was considered acceptable [31].

\subsection{Database}

In total, we measured 355 fractured planes, striations, and unconformities in 196 outcrops along the coastal areas from Tuy Hoa, Ke Ga, and Vung Tau to Phu Quy Island. Residual friction angles of 34 granite samples in Cai Mep Port were measured using triaxial tests at depths of $90-173 \mathrm{~m}$ [32].

The offshore dataset included in situ stresses from 13 wells, which were measured in eight EXtended LeakOff Tests (XLOT), and 23 Formation Micro-Imager (FMI). Twelve earthquake focal mechanisms were analyzed from 315 earthquakes detected between 2002 and May 2020. During this period, earthquakes mainly occurred along the NNE-SSW fault zone in and adjacent to the White Tiger-Rong fields (Fig. 2). We also interpreted 239 faults based on $14000 \mathrm{~km}$ of regional offshore seismic data from the Cuu Long Basin [33].

\subsubsection{Statistical data analyses}

Owing to the geological heterogeneity of fault systems, the coefficient of shear friction changes randomly. As the shear friction coefficient profiles were determined by the probability distribution function, a Monte Carlo simulation allows the use of these distributions and independent or dependent random variables [34]. In this study, the normal distribution

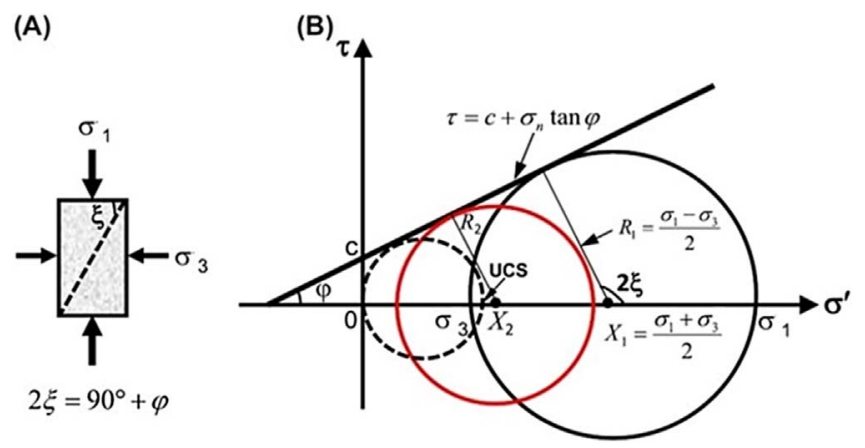

Fig. 3. Mohr-Coulomb failure criterion in the effective stress domain. (a) Shear plane under triaxial compression. (b) Mohr circles and an attenuation contour cut linearly (tangential line of the Mohr circles), where $\theta$ is the angle of internal friction.

was used as the variable $(x)$, with the mean and variance, $\sigma^{2}$, based on the following function:

$$
f(x)=\frac{1}{\sigma \sqrt{2 \pi}} \mathrm{e}^{-(x-\mu)^{2} / 2 \sigma^{2}},
$$

where the mean is:

$$
\mu=\frac{1}{n} \sum_{i=1}^{n} x_{i}
$$

and the variance is given by:

$$
\sigma^{2}=\frac{\sum(x-\mu)^{2}}{n} .
$$




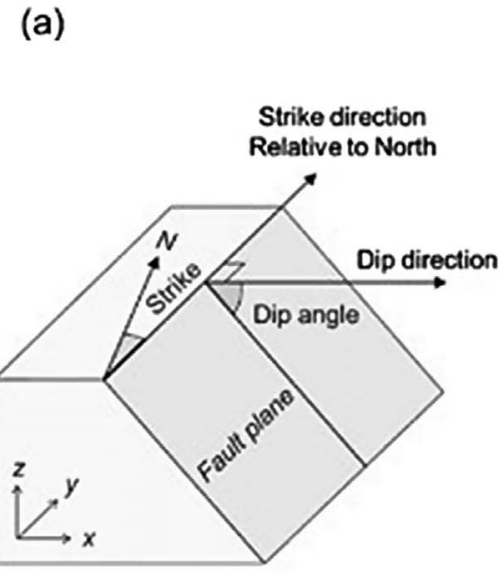

Fig. 4. Fracture parameters and stress state analysis.

\subsection{Workflow}

The Mohr circle diagram demonstrates the relationship between the stress state and rheology of rocks in the crust and lithosphere. This diagram shows the stress ratio, which predicts the growth of new ruptures and the reactivation of existing faults.

The internal friction angle can be described as the shear strength due to friction according to the effective normal stress prescribed by the Mohr-Coulomb failure condition. The internal friction angle was determined using the shear and normal stresses at various levels (Fig. 3). According to the Mohr-Coulomb circle, the slope of the curve related to the shear strength and compressional pressure is the internal friction angle.

The following assumptions were made to calculate the coefficients of shear friction:

1. brittle deformation must comply with the MohrCoulomb failure standard;

2. the shear friction coefficient of an existing fault before the occurrence of critical sliding was constant for a specific tectonic regime. The faults could be strikeslip, normal, or reverse types;

3. the normalized Mohr circle was based on the stress ratio in the region corresponding to the tectonic regime. Simplified principal stress intensities were $\sigma_{3}=0, \sigma_{1}=1$, and $\sigma_{2}=$ the stress ratio. For example, if the stress ratio was 0.7 , then $\sigma_{2}=0.7$ on the Mohr circle; and

4. the tensors of the principal stress axes $\left(\sigma_{1}, \sigma_{2}\right.$, and $\left.\sigma_{3}\right)$ were similar to the regional stress tensors.

This study analyzed the conjugate fault system and the ratio of normal to shear stress based on measured fault profiles to achieve a robust approach to understand the shear friction coefficient. The process of estimating the friction coefficient proceeded as follows:

Step 1: Conduct field measurements on sliding surfaces: dip directions, dip angles, and the directions of the motion vectors (Fig. 4).

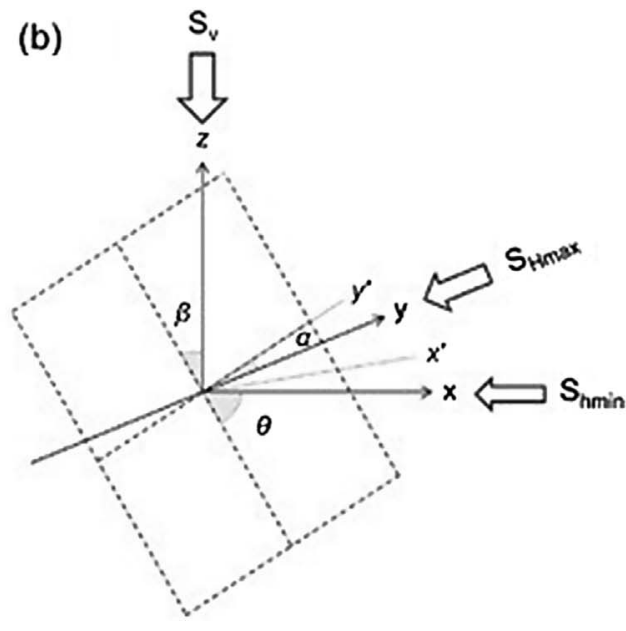

Step 2: Classify the striation data according to petrographic compositions:

+ Late Cretaceous granite from the Deo Ca complex.

+ Intrusive basalt from the late Miocene Dai Nga complex, Pliocene to early Pleistocene Tuc Trung complex, and middle Pleistocene Xuan Loc complex in Ba Ria-Vung Tau province.

+ Cretaceous rhyolites from the Nha Trang complex.

Step 3: Build a contour diagram of fractures/striations using the Stereonet 10.0 software [35] to find the maximum values. Each maximum value corresponding to a specified dip direction and dip angle that represented a group of striations was identified.

Step 4: Estimate the conjugate angles between striation pairs (conjugate deformation). Two fractures/striations were considered to be conjugates when they formed an angle of $30^{\circ}-89^{\circ}$ [36]. We used the Dips 8.0 software package to determine the striation pairs.

Step 5: Calculate the static friction angles based on the measured conjugate angles using the equation in [37]:

$$
\Phi=90-\theta,
$$

where $\Phi$ is the static friction angle and $\theta$ is the conjugate angle. The relationship between the conjugate friction angle and the shear friction coefficient is given by:

$$
\begin{gathered}
\theta=1 / 2 \arctan (1 / \mu) \quad \text { and } \\
\theta=0 \text { and } \theta=2 \theta^{*}
\end{gathered}
$$

where $\theta^{*}$ is the minimum reactivation friction angle or optimal angle.

Step 6: Based on the dataset's friction angles, we performed statistical analyses to estimate the range of values.

The friction angles were determined using an appropriate probability distribution function in two steps:

Step 1: The type of random distribution was hypothesized by analyzing the available data. The proposed 


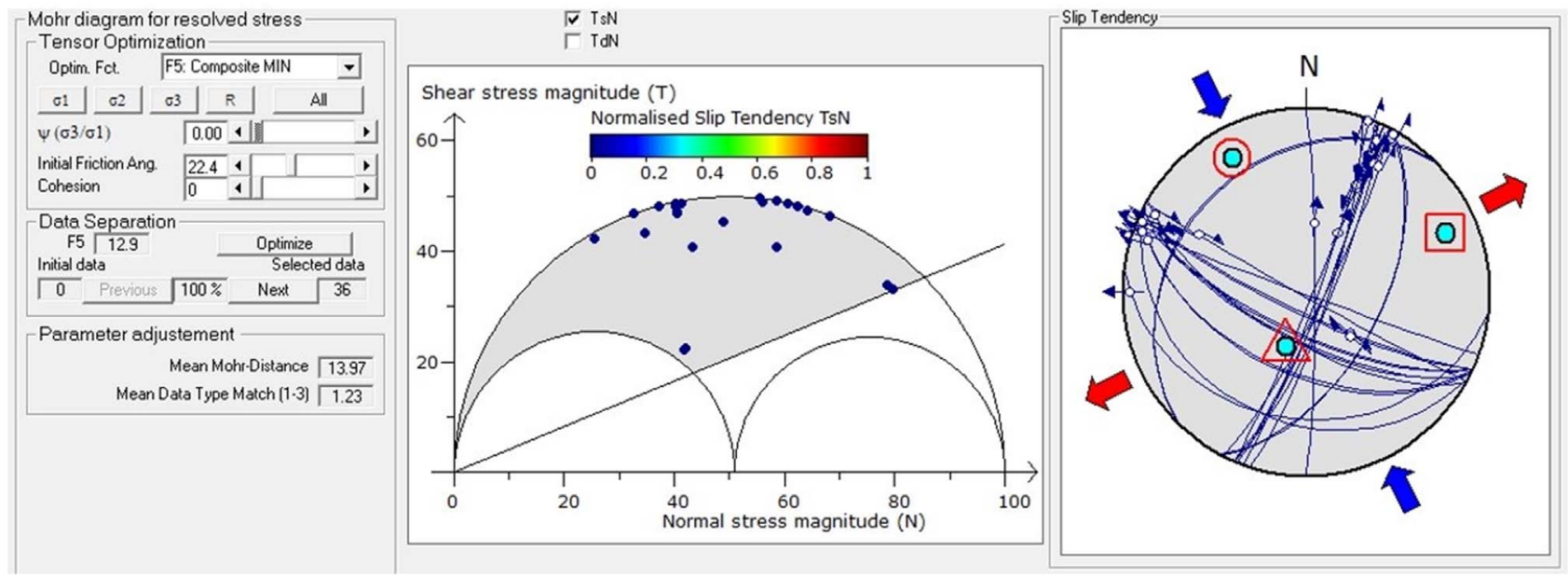

Fig. 5. Analysis of the friction angles from 12 earthquake focal mechanisms.

Table 6. Estimation of friction angles based on earthquake focal mechanisms.

\begin{tabular}{|c|c|c|c|c|c|c|c|c|}
\hline \multirow[t]{2}{*}{ No } & \multicolumn{2}{|c|}{ Fault plane 1} & \multicolumn{2}{|c|}{ Fault plane 2} & \multirow{2}{*}{$\begin{array}{c}\text { Conjugated } \\
\text { angle } \\
\text { (degree) }\end{array}$} & \multirow{2}{*}{$\begin{array}{c}\text { Friction } \\
\text { static angle } \\
\text { (degree) }\end{array}$} & \multirow{2}{*}{$\begin{array}{l}\text { Coefficient } \\
\text { of friction }\end{array}$} & \multirow{2}{*}{$\begin{array}{c}\text { Optimal } \\
\text { angle, } \\
\theta^{*} \text { (degree) }\end{array}$} \\
\hline & $\begin{array}{l}\text { Dip-direction } \\
\text { (degree) }\end{array}$ & $\begin{array}{l}\text { Dip-direction } \\
\text { (degree) }\end{array}$ & $\begin{array}{l}\text { Dip-direction } \\
\text { (degree) }\end{array}$ & $\begin{array}{l}\text { Dip-direction } \\
\text { (degree) }\end{array}$ & & & & \\
\hline 1 & 40 & 72 & 90 & 86 & 51 & 39 & 0.81 & 25.5 \\
\hline 2 & 40 & 72 & 111 & 84 & 70 & 20 & 0.36 & 35 \\
\hline 3 & 40 & 72 & 120 & 57 & 72 & 18 & 0.32 & 36 \\
\hline 4 & 40 & 72 & 122 & 32 & 71 & 19 & 0.34 & 35.5 \\
\hline 5 & 40 & 72 & 200 & 58 & 54 & 36 & 0.73 & 27 \\
\hline 6 & 40 & 72 & 256 & 68 & 53 & 37 & 0.75 & 26.5 \\
\hline 7 & 40 & 72 & 312 & 30 & 73 & 17 & 0.31 & 36.5 \\
\hline 8 & 90 & 86 & 120 & 57 & 40 & 50 & 1.19 & 20 \\
\hline 9 & 90 & 86 & 122 & 32 & 60 & 30 & 0.58 & 30 \\
\hline 10 & 90 & 86 & 200 & 58 & 75 & 15 & 0.27 & 37.5 \\
\hline 11 & 90 & 86 & 312 & 30 & 72 & 18 & 0.32 & 36 \\
\hline 12 & 111 & 84 & 122 & 32 & 53 & 37 & 0.75 & 26.5 \\
\hline 13 & 111 & 84 & 200 & 58 & 86 & 4 & 0.07 & 43 \\
\hline 14 & 111 & 84 & 256 & 68 & 44 & 46 & 1.04 & 22 \\
\hline 15 & 111 & 84 & 312 & 30 & 68 & 22 & 0.40 & 34 \\
\hline 16 & 120 & 57 & 200 & 58 & 66 & 24 & 0.45 & 33 \\
\hline 17 & 120 & 57 & 256 & 68 & 69 & 21 & 0.38 & 34.5 \\
\hline 18 & 120 & 57 & 312 & 30 & 86 & 4 & 0.07 & 43 \\
\hline 19 & 122 & 32 & 200 & 58 & 57 & 33 & 0.65 & 28.5 \\
\hline 20 & 122 & 32 & 256 & 68 & 89 & 1 & 0.02 & 44.5 \\
\hline 21 & 122 & 32 & 312 & 30 & 62 & 28 & 0.53 & 31 \\
\hline 22 & 200 & 58 & 256 & 68 & 50 & 40 & 0.84 & 25 \\
\hline 23 & 200 & 58 & 312 & 30 & 73 & 17 & 0.31 & 36.5 \\
\hline 24 & 256 & 68 & 312 & 30 & 54 & 36 & 0.73 & 27 \\
\hline
\end{tabular}

$\theta^{*}$ - angle between maximum principal stress axis and the fault slip plane. 
Table 7. Estimation of friction angles based on pairs of conjugated faults in the Oligocene sandstone and fractured granite reservoirs in the White Tiger field.

\begin{tabular}{|c|c|c|c|c|c|c|}
\hline \multirow[t]{2}{*}{ No } & \multicolumn{2}{|c|}{ Fault plane 1} & \multicolumn{2}{|c|}{ Fault plane 2} & \multirow{2}{*}{$\begin{array}{c}\text { Conjugated angle, } \\
\text { (degree) }\end{array}$} & \multirow{2}{*}{$\begin{array}{l}\text { Static friction } \\
\text { angle (degree) }\end{array}$} \\
\hline & Dip-direction (degree) & Dip (degree) & Dip-direction (degree) & Dip (degree) & & \\
\hline 1 & 14 & 45 & 68 & 54 & 41 & 49 \\
\hline 2 & 14 & 45 & 93 & 78 & 74 & 16 \\
\hline 3 & 14 & 45 & 120 & 42 & 67 & 23 \\
\hline 4 & 14 & 45 & 189 & 68 & 67 & 23 \\
\hline 5 & 14 & 45 & 202 & 18 & 63 & 27 \\
\hline 6 & 14 & 45 & 212 & 40 & 84 & 6 \\
\hline 7 & 14 & 45 & 303 & 66 & 60 & 30 \\
\hline 8 & 14 & 45 & 328 & 40 & 31 & 59 \\
\hline 9 & 68 & 54 & 93 & 78 & 33 & 57 \\
\hline 10 & 68 & 54 & 117 & 76 & 49 & 41 \\
\hline 11 & 68 & 54 & 120 & 42 & 40 & 50 \\
\hline 12 & 68 & 54 & 189 & 68 & 80 & 10 \\
\hline 13 & 68 & 54 & 202 & 18 & 67 & 23 \\
\hline 14 & 68 & 54 & 212 & 40 & 88 & 2 \\
\hline 15 & 68 & 54 & 303 & 66 & 79 & 11 \\
\hline 16 & 68 & 54 & 328 & 40 & 69 & 21 \\
\hline 17 & 93 & 78 & 120 & 42 & 42 & 48 \\
\hline 18 & 93 & 78 & 202 & 18 & 84 & 6 \\
\hline 19 & 93 & 78 & 212 & 40 & 82 & 8 \\
\hline 20 & 93 & 78 & 303 & 66 & 46 & 44 \\
\hline 21 & 93 & 78 & 328 & 40 & 78 & 12 \\
\hline 22 & 117 & 76 & 120 & 42 & 34 & 56 \\
\hline 23 & 117 & 76 & 189 & 68 & 68 & 22 \\
\hline 24 & 117 & 76 & 202 & 18 & 75 & 15 \\
\hline 25 & 117 & 76 & 212 & 40 & 82 & 8 \\
\hline 26 & 117 & 76 & 303 & 66 & 38 & 52 \\
\hline 27 & 117 & 76 & 328 & 40 & 70 & 20 \\
\hline 28 & 120 & 42 & 189 & 68 & 60 & 30 \\
\hline 29 & 120 & 42 & 202 & 18 & 43 & 47 \\
\hline 30 & 120 & 42 & 212 & 40 & 56 & 34 \\
\hline 31 & 120 & 42 & 303 & 66 & 72 & 18 \\
\hline 32 & 120 & 42 & 328 & 40 & 79 & 11 \\
\hline 33 & 189 & 68 & 202 & 18 & 51 & 39 \\
\hline 34 & 189 & 68 & 212 & 40 & 33 & 57 \\
\hline 35 & 189 & 68 & 303 & 66 & 79 & 11 \\
\hline 36 & 189 & 68 & 328 & 40 & 81 & 9 \\
\hline 37 & 202 & 18 & 303 & 66 & 71 & 19 \\
\hline 38 & 202 & 18 & 328 & 40 & 52 & 38 \\
\hline 39 & 212 & 40 & 303 & 66 & 72 & 18 \\
\hline 40 & 212 & 40 & 328 & 40 & 66 & 24 \\
\hline 41 & 303 & 66 & 328 & 40 & 32 & 58 \\
\hline
\end{tabular}




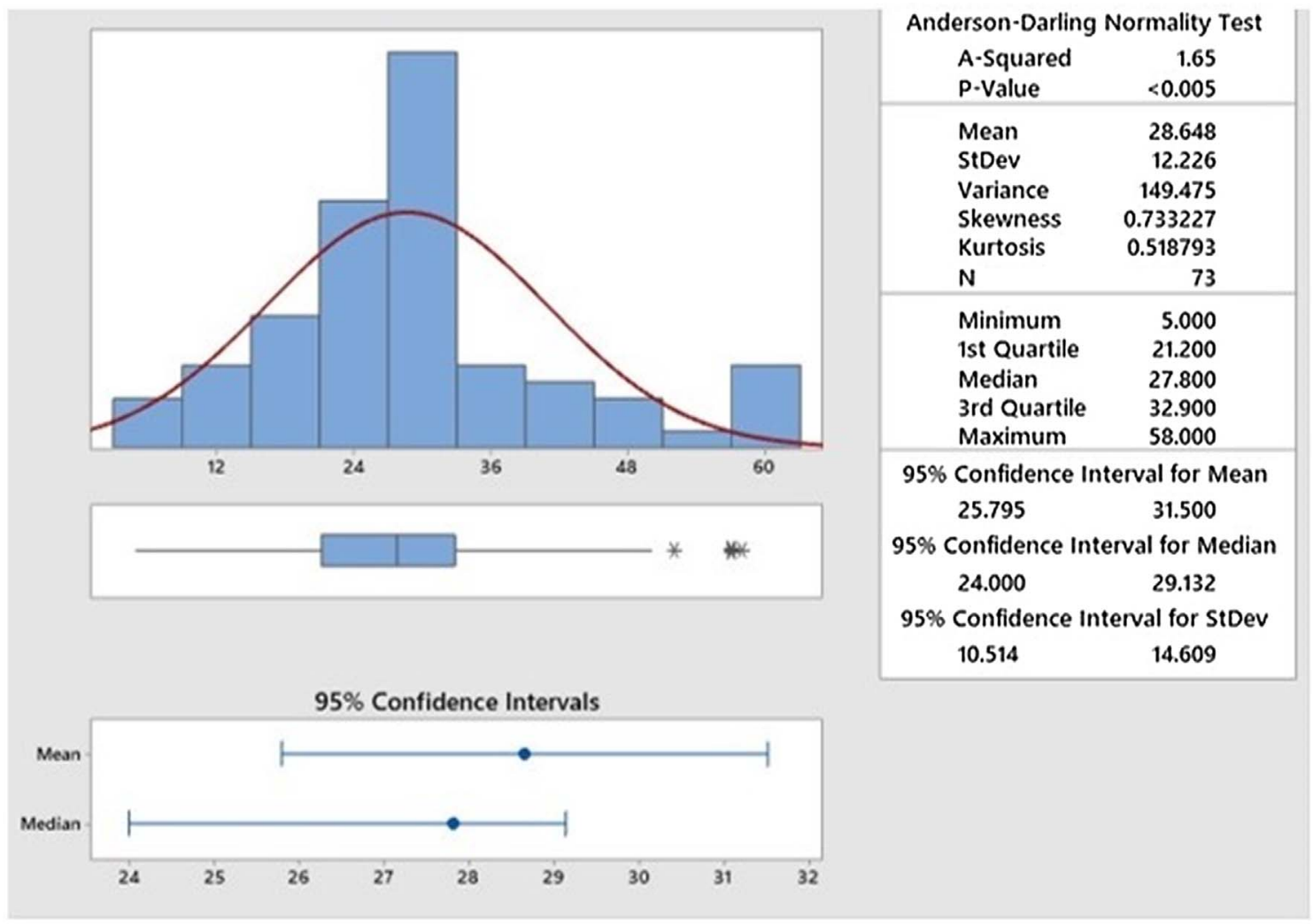

Fig. 6. Summary of the statistical parameters for onshore friction angles.

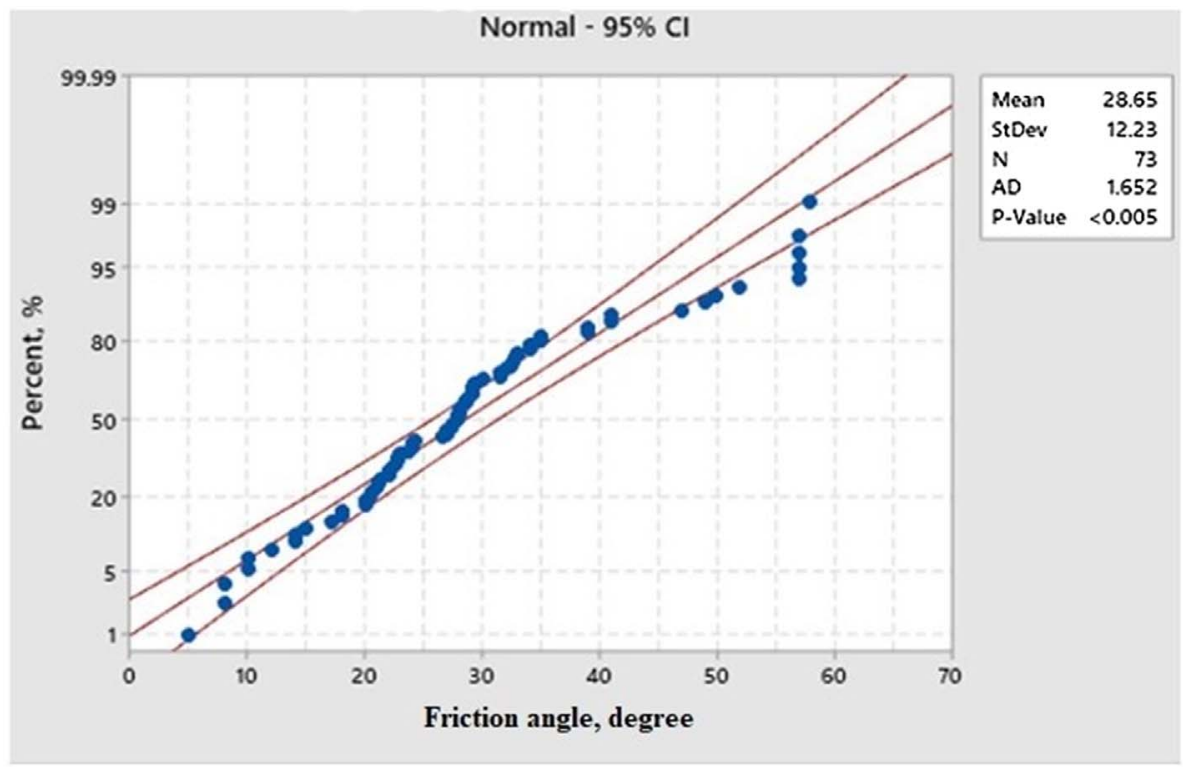

Fig. 7. Threshold of the onshore friction angle value.

distribution assumed that the friction angle types conform to normal, log-normal, and beta distributions.

Step 2: The goodness-of-fit test was used to evaluate the distribution type by fitting the theoretical distribution to the hypothetical distribution at a specified significance level.

\section{Results}

Twelve earthquake focal mechanisms were measured by the Vietnam Institute of Geophysics using the technique reported in [36] technique to analyze 24 conjugate angles based on conjugate fault pairs (Fig. 5). Thus, 24 friction angles were calculated (Tab. 6). 


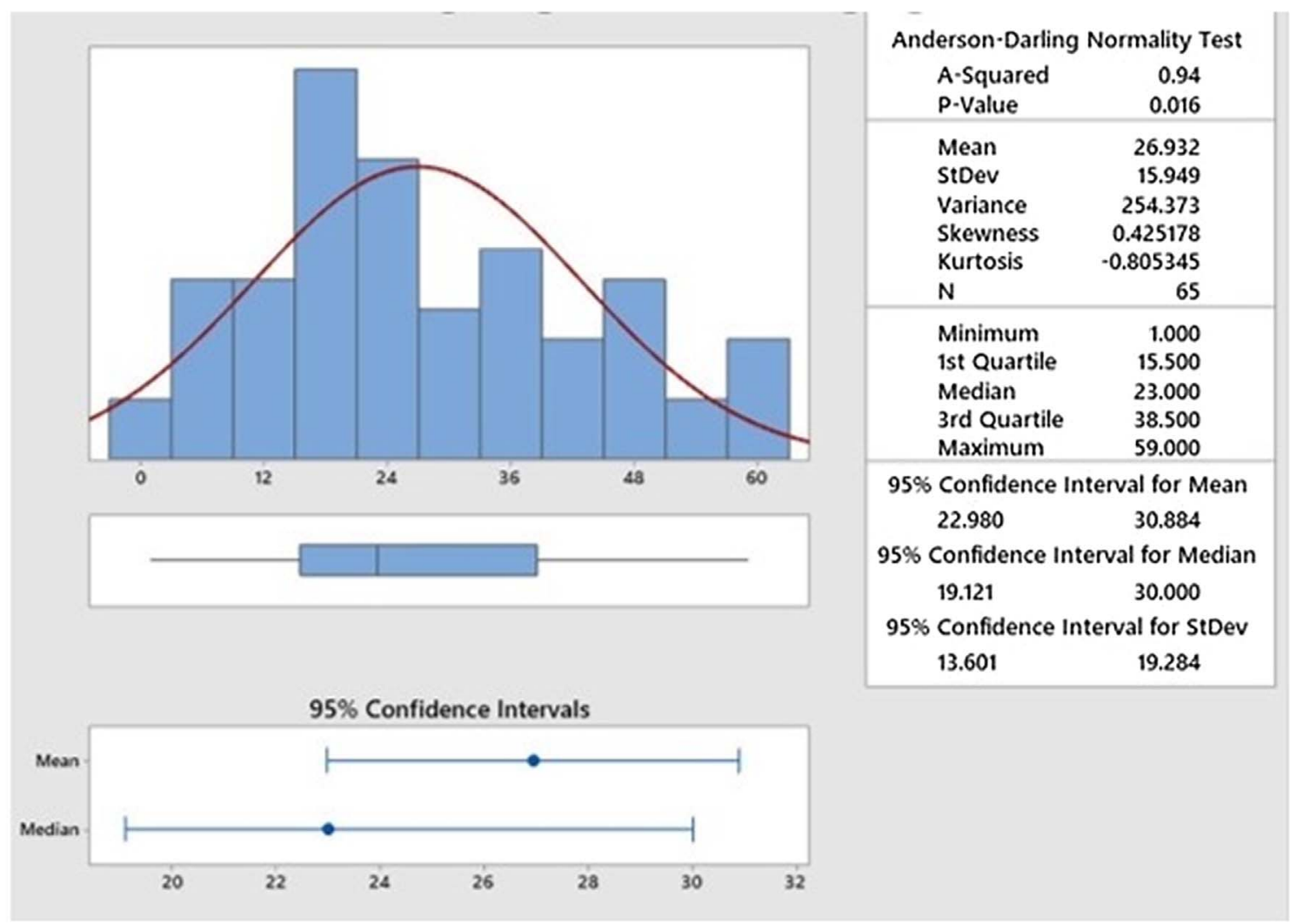

Fig. 8. Summary of the statistical parameters for offshore friction angles.

Based on the Mohr circle failure standard, the calculated conjugate angles of fault pairs are represented by points on the Mohr circle. From the 11 fault systems in the White Tiger structure and its vicinity, 41 pairs of conjugate angles were determined and plotted on the Mohr circle. The ratios of shear to normal stresses in the fault profiles in the White Tiger field and adjacent areas were calculated based on data from 239 faults (Tab. 7).

\section{Coastal region near Tuy Hoa, Ke Ga, and Vung Tau}

The profiles show that the friction angle of the fault system varied from $5^{\circ}$ to $58^{\circ}$. The standard deviation and mean values were $12.23^{\circ}$ and $27.65^{\circ}$, respectively. The dataset consisted of 73 samples and had a $p$-value of $<0.005$, indicating statistical significance. Therefore, the probability analysis had a very high confidence interval, confirming that the average value of the friction angle was between $25.8^{\circ}$ and $31.5^{\circ}$. A histogram of the data exhibited a normal distribution, confirming that the results were reliable (Fig. 6).

\section{Tolerance interval of the onshore region}

The points on the graph were almost linear, indicating that the dataset had a normal distribution. In addition, the $p$-value was significant ( $\alpha=0.05$ ), confirming that the data had a normal distribution (Fig. 7). For the onshore region, the low threshold was $24^{\circ}$ (Fig. 6). Figure 7 shows a friction angle of $24^{\circ}$ in the 20th percentile based on the diagram.
Therefore, $\sim 20 \%$ of the friction angles were equal to or less than this value while $\sim 80 \%$ of the friction angles were greater than $24^{\circ}$.

\subsection{Offshore area from Tuy Hoa to the White Tiger field}

The histogram of a dataset consisting of 65 calculated friction angles for a wide range of values $\left(1-59^{\circ}\right)$ had a normal distribution (Fig. 8). The $p$-value was 0.016 , or less than $\alpha=5 \%$, indicating that the dataset was statistically significant. The mean and standard deviation were $15.95^{\circ}$ and $26.93^{\circ}$, respectively. The average friction angle was in the range of $23-31^{\circ}$ with high reliability.

\subsection{Tolerance interval of the offshore region}

The normal probability distribution plot shows that the points are almost linear, indicating that the data have a normal distribution. In addition, the $p$-value for the test was 0.016, which was smaller than the significance level $(\alpha=0.05)$. This confirms that the data have a normal distribution (Fig. 9).

According to [3] theory of friction, the initial friction angle was measured at $16.7^{\circ}$, which is the lower limit for sliding faults in all conditions. However, in the White Tiger field and adjacent areas, the lowest value of the median was $19.12^{\circ}$. Hence, this value should be used as the lower 


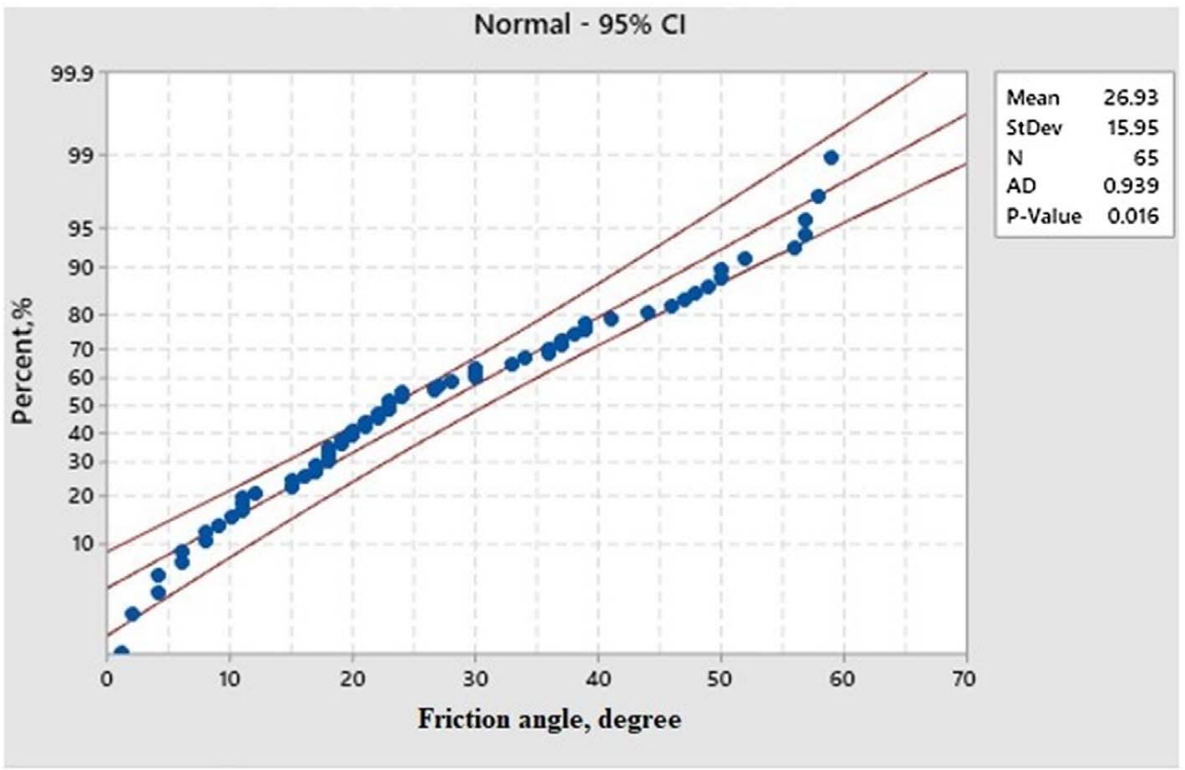

Fig. 9. Threshold of the offshore friction angle value.

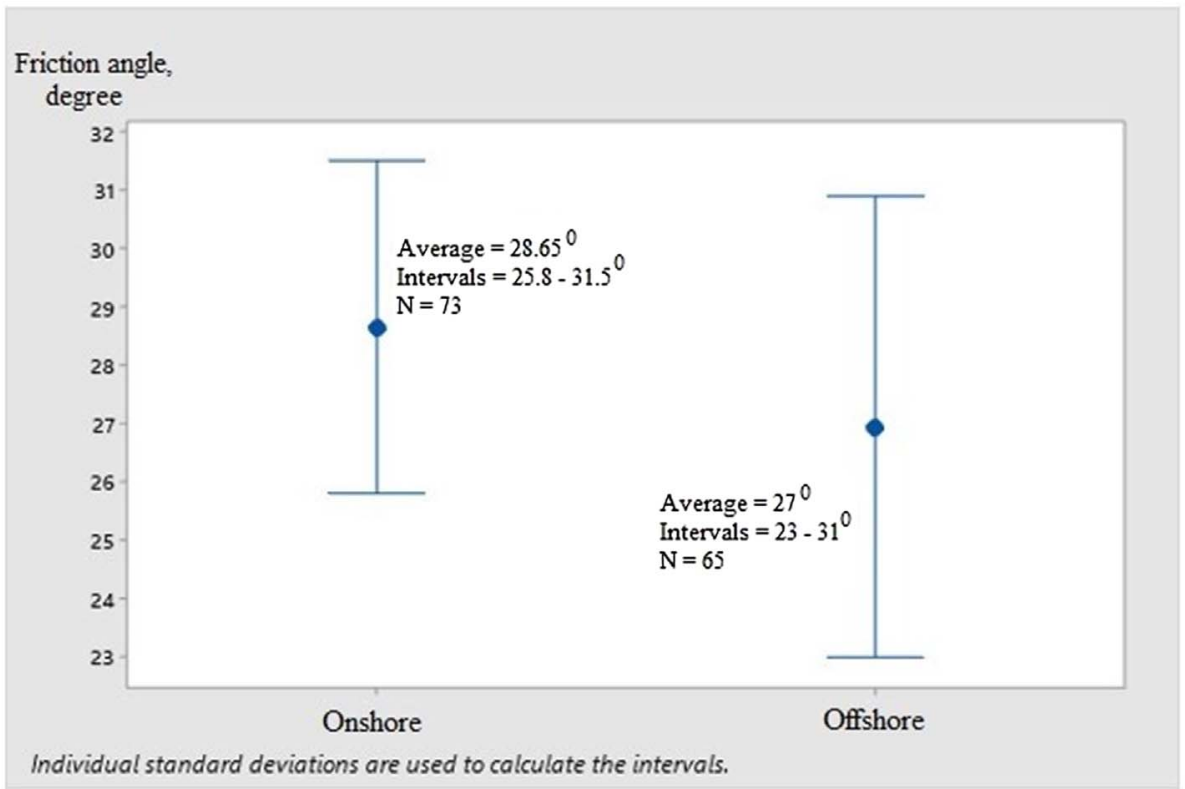

Fig. 10. Threshold of the friction angle at a $95 \%$ confidence level.

threshold (Fig. 8). Figure 9 shows that a slip friction angle of $19.12^{\circ}$ was in the 38 th percentile. Thus, $\sim 38 \%$ of the friction angles were equal to or less than $19.12^{\circ}$ and $\sim 62 \%$ of the friction angles were greater than $19.12^{\circ}$.

\subsection{Determining threshold values of onshore and offshore friction angles}

One of the main challenges that occurs when performing reliability analysis is the determination of the range of acceptable friction angles. From this perspective, a high confidence level (95\%) was selected as the threshold for the mean values in each surveyed area (Fig. 10):

For the onshore region: The threshold value ranged from $25.8^{\circ}$ to $31.5^{\circ}$ with an average of $28.65^{\circ}$.

For the offshore region: The threshold value ranged from $23^{\circ}$ to $31^{\circ}$ with an average of $27^{\circ}$. The initial friction angle chosen was the lowest median value $\left(19.12^{\circ}\right)$, corresponding to a frictional coefficient of 0.35 , which is considered a low threshold for slipping faults in all conditions. 
The chart in Figure 10 shows that the friction angles in the offshore region were, on average, $1.65^{\circ}$ lower than those of the onshore region. Thus, the equivalent offshore coefficient of friction was 0.51 while that of the onshore region was 0.55 .

\section{Discussion}

As estimating the friction angle of a sliding fault is difficult [6], previous studies have assumed a wide range for the coefficient of friction (0.6-0.85), equivalent to a friction angle of 31-40 [3]. When compared with the results of this study, the lowest coefficient of friction obtained using the method proposed in [3] was equal to the upper threshold found for the offshore area of Vietnam. Therefore, applying the friction angle of [3] caused uncertainty in forecasting the sliding tendency in the Tuy Hoa-Vung Tau region.

Sibson [37] suggested that reactivated inverse faults have high slope angles, indicating that the optimal angle, $\theta^{*}$ (equal to half of the conjugate angle), is $60^{\circ}$ or greater. When the reactivated fault has a low slope angle, $\theta^{*}$ is in the range of $20-30^{\circ}$, which reflects the frictional coefficient anomaly. This evidence is related to water injection and formation damage caused by human activity. The four earthquake focal mechanisms with conjugate fault plane angles in the range of $20-30^{\circ}$ may have been caused by the impact of water injection, hydraulic fracturing, or abnormal pore pressures due to production activities.

The analysis in $[8]$ suggests that any fault with a friction angle of $\phi<20^{\circ}$ will slip if the optimal $\theta^{*}$ angle is $30-40^{\circ}$. If the friction angle of a fault is $<15^{\circ}$, the fault will slip within the direction range of $15^{\circ}<\theta<60^{\circ}$. Faults with friction angles $>22^{\circ}$ will not slip in any direction.

For in situ stress and borehole pressures in the Cuu Long Basin, friction angles of $48-57^{\circ}$ obtained for wells $\mathrm{A}$ and $\mathrm{B}$ in the brittle fractured granite reservoir indicate deformation at depths of $4000-4300 \mathrm{~m}$ [17]. This result is inaccurate because the value of $48^{\circ}-57^{\circ}$ was outside the allowable confidence interval, which led to incorrect well drilling design and determinations of the injected water volume threshold. This result was locally calculated and is not an expected value for most of the Cuu Long Basin oilfield.

For the stress field state at the wells in the Chu Long and Nam Con Son basins [18], a frictional coefficient of 0.5 was used to calculate the maximum horizontal stress for the normal strike-slip fault, which is equivalent to a friction angle of $26.6^{\circ}$. The assumed frictional coefficient was appropriate because the results were similar to those obtained in this study. A comparison of the Leak-Off Test (LOT) and hydraulic fracturing in several boreholes indicates that the maximum horizontal stress was 60$64 \mathrm{MPa}$. Thus, using a friction angle of $27^{\circ}$ and a stress ratio of 0.51 was appropriate for the LOT test conditions.

By investigating the role of the friction coefficient in terms of the optimal slip angle of a fault, King et al. [38] found that a lower friction angle results in an optimal angle, $\theta$, between the two slip plane faults closer to $90^{\circ}$. In contrast, a higher friction angle results in a smaller optimal angle, $\theta$. The friction angle is important for assessing sensitivity to changes in the Coulomb stress and the effect that present-day tectonic stress fields have on strike-slip faults with changes in the coefficient of friction. The lowest friction angle is usually $8^{\circ}$ to $18^{\circ}$ for reactivation faults in coal mines [8].

Computations using the Coulomb v3.3 software package on changes in stress and deformation have suggested that the San Andres fault could cause earthquakes, with a frictional coefficient of $0.4-0.45$, corresponding to a friction angle of 21.8-24.2 $2^{\circ}$ [39]. This is a lower threshold for the sliding friction angle of faults for normal earthquakes. If the value is abnormally higher or lower than the range of frictional slip fault angle, there are two possibilities:

1. Fluid injection can be used to increase pore pressure or create hydraulic stimulation [37];

2. The fault anomalies are filled with clay minerals or coal, or have been mineralized.

Therefore, the prediction of the lower limit of the friction angle of major fault systems in the Bach Ho oilfield indicated that slippage can occur. Hence, the consideration of appropriate volumes of water injection and drilling design are important parameters for preventing slip. For estimations, a lower shear friction angle threshold of $23^{\circ}$, or a frictional coefficient of 0.42 can be used for this area.

Abnormal faults with small friction angles can cause slip in high pore pressure conditions. Clay that fills in a fault plane can also reduce the frictional resistance, leading to slip with very small friction angles of $1-2^{\circ}[6,40,41]$. The data in Tables 2 and 3 indicate that some conjugate faults with very low shear friction angles can cause slip because of clay mineral infill along the faults.

Barton and Choubey [42] conducted experiments to determine the static friction coefficients of different rocks, showing that sedimentary rocks slide on magmatic rocks (or vice versa) due to the residual friction angle of the fissure or natural fracture at an angle of $28-32^{\circ}$. These values lowered the upper threshold for the range of the friction angle to $23-31^{\circ}$.

The modern stress field in the coastal area of Tuy HoaVung Tau was assumed to have an average coefficient of friction, i.e., $\mu=0.5$ (friction angle of $26.6^{\circ}$ ) at a depth of $5 \mathrm{~km}$, which almost coincides with the offshore value obtained in this study. Calculation results show high reliability corresponding to the vertical, maximum horizontal, and minimum stresses of 127,158 , and $90.5 \mathrm{MPa}$, respectively. The estimated pore pressure was $49.1 \mathrm{MPa}$ [43].

Multi-stage triaxial compression tests for the confinement conditions at $20^{\circ} \mathrm{C}$ in natural granite fragments show that the average friction angle at normal temperatures is $29.3^{\circ}$ [44], which has a deviation of $0.65^{\circ}$ from the onshore friction angle estimated in this study. At $80^{\circ} \mathrm{C}$, the friction angle was reduced to $27.87^{\circ}$, which is similar to the friction angle of $27^{\circ}$ estimated for the offshore region at a depth of $4000 \mathrm{~m}$.

Dung et al. [45] used a critical frictional coefficient of $\mu=0.6$ to determine the direction of open fractures in the granite basement of the Cuu Long Basin. The results showed two main directions of the critical stress fractures: 
(1) north-south, with a dip direction toward the east or west and a dip angle of $\sim 75^{\circ}$, and (2) northwest-southeast, with a dip direction toward the northeast or southwest and a dip angle of $\sim 75^{\circ}$. The frictional coefficient $(\mu=0.6$, corresponding to a friction angle of $31^{\circ}$ ) of the basement rock coincides with the upper threshold of the average value estimated in this study.

\section{Conclusion}

The estimation of statistical probability is an essential tool used in modern data analysis. The main goal of this study was to statistically process a friction angle dataset. The ranges of acceptable threshold values (minimum, mean, and maximum) at a 95\% confidence level confirm the normal distributions of data from each of the studied regions. The estimates can be summarized as follows:

Onshore region: The threshold value ranged from $25.8^{\circ}$ to $31.5^{\circ}$, with an average of $28.65^{\circ}$, according to a frictional coefficient of 0.55 .

Offshore region: The threshold value ranged from $23^{\circ}$ to $31^{\circ}$, with an average of $27^{\circ}$, according to a frictional coefficient of 0.51 .

The recommended initial friction angle is the lowest median value $\left(19.12^{\circ}\right)$ obtained for the offshore area, which is higher than the $16.7^{\circ}$ angle obtained when using the method of [3]. The estimations of the friction coefficients and friction angles using statistical analyses are highly reliable and can contribute significantly to other underground resource exploitation projects in the study area.

The study was limited by any measurement error associated with the fracture morphology and from the sliding angles of kinematic faults. Errors and confusion regarding the identification of the conjugate angles in outcrops may have also occurred.

Future research should focus on building and classifying kinematic fractures in rock types with different ages. An improved identification method for matching pairs of conjugate fractures in outcrops is also required. Furthermore, we must develop an isometric map of the distribution of frictional coefficients, friction angles, and fracture strengths to further aid in the design of underground wells and resource exploitation.

Acknowledgments. This research is funded by the Office of National Science and Technology Research Programs, the Ministry of Science and Technology under grant number KC.09.38/16-20. We appreciate Vietnam-Russia Joint Venture, Hyosung Vina Petrochemical Co., Ltd, and Hoan Long - Hoan $\mathrm{Vu}$ JOC for providing the valuable data. In addition, this research is funded by the Ministry of Science and Technology of Vietnam, under grant number NĐT.48.KR/18. We would like to thank General Department of Geology and Minerals of Vietnam, Ministry of Natural Resource and Environment, $\mathrm{Ho}_{\mathrm{o}}$ Chi Minh City University of Technology (HCMUT), and University of Science $V N U-H C M$ for allowing the use of facilities during this study.

\section{References}

1 Wyllie D.C., Norrish N.I. (1996) Rock strength properties and their measurement, TRB Special Report 247, pp. 372-390.

2 Wyllie D.C. (2014) Rock fall engineering, CRC Press.

3 Byerlee J. (1978) Friction of rocks, in: Byerlee J.D., Wyss M. (eds), Rock friction and earthquake prediction, Birkhäuser, Basel, pp. 615-626.

4 Barton N. (1973) Review of a new shear-strength criterion for rock joints, Eng. Geol. 7, 4, 287-332.

5 Jaeger J.C., Cook N.G., Zimmerman R. (2009) Fundamentals of rock mechanics, John Wiley \& Sons.

6 Yukutake Y., Takeda T., Yoshida A. (2015) The applicability of frictional reactivation theory to active faults in Japan based on slip tendency analysis, Earth Planet Sci. Lett. 411, 188-198.

7 Middleton T.A., Copley A. (2014) Constraining fault friction by re-examining earthquake nodal plane dips, Geophys. J. Int. 196, 2, 671-680.

8 Alber M. (2013) Strength of faults - A concern for mining engineers? in: ISRM International Symposium-EUROCK 2013, International Society for Rock Mech Rock Eng.

9 Tamura H., Kambayashi Y. (2016) Estimation of the coefficient of static friction of surface by analyzing photo images, in: Czarnowski I., Caballero A., Howlett R., Jain L. (eds), Intelligent Decision Technologies 2016, Springer, Cham, pp. 15-26.

10 Hencher S.R. (1989) Laboratory direct shear testing of rock discontinuities, Ground Eng. 22, 2, 24-31.

11 Hencher S.R. (1995) Interpretation of direct shear tests on rock joints, in: Proceedings 35th US Symposium on Rock Mechanics, Lake Tahoe, pp. 99-106.

12 Hencher S.R. (2012) Discussion of Alejano, Gonzalez and Muralha (2012), Rock. Mech. Rock. Eng. 45, 6, 11371139 .

13 Ghani R.A., Goh T.L., Hariri A.M., Baizura Y.N. (2011) Field and laboratory-based approach for the determination of friction angle of geological discontinuities of Malaysian granites, ASEAN J. Sci. Technol. Dev. 28, 2, 151-155.

14 Boulton C., Barth N.C., Moore D.E., Lockner D.A., Townend J., Faulkner D.R. (2018) Frictional properties and 3-D stress analysis of the southern Alpine Fault, New Zealand, J. Struct. Geol. 114, 43-54.

15 Jeanne P., Rutqvist J., Foxall W., Rinaldi A.P., Wainwright H.M., Zhou Q., Birkholzer J., Layland-Bachmann C. (2017) Effects of the distribution and evolution of the coefficient of friction along a fault on the assessment of the seismic activity associated with a hypothetical industrial-scale geologic $\mathrm{CO}_{2}$ sequestration operation, Int. J. Greenh. Gas Control 66, 254-263.

16 Anderson E.M. (1951) The dynamics of faulting and dyke formation with applications to Britain, Oliver and Boyd.

17 Binh N.T.T., Tokunaga T., Okui A. (2004) In-situ stress and pore pressure fields in the North Cuu Long Basin, offshore Vietnam, in: SPE Asia Pacific Conference on Integrated Modelling for Asset Management, Society of Petroleum Engineers.

18 Binh N.T.T., Tokunaga T., Goulty N.R., Son H.P., Van Binh M. (2011) Stress state in the Cuu Long and Nam Con Son basins, offshore Vietnam, Mar. Pet. Geol. 28, 5, 973-979. 
19 Gan Q., Elsworth D. (2014) Analysis of fluid injectioninduced fault reactivation and seismic slip in geothermal reservoirs, J. Geophys. Res. Solid Earth 119, 4, 3340-3353.

20 Lama R.D., Vutukuri V.S. (1978) Handbook on mechanical properties of rocks-testing techniques and results-volume iii, Vol. 3, No. 2, Trans Tech Publications.

21 Son H.V., Khanh P.D., Dung P.T. (2015) Analyzing the effect of the stress field on the wellbore stability, Bachelor thesis, Ho Chi Minh University of Technology, Vietnam.

22 Sato K. (2016) A computerized method to estimate the friction coefficient from the orientation distribution of Meso-scale faults, J. Struct. Geol. 89, 44-53.

23 Gephart J.W., Forsyth D.W. (1984) An improved method for determining the regional stress tensor using earthquake focal mechanism data: application to the San Fernando earthquake sequence, J. Geophys. Res. Solid Earth 89, B11, 9305-9320.

24 Michael A.J., Geller R.J. (1984) Linear moment tensor inversion for shallow thrust earthquakes combining firstmotion and surface wave data, J. Geophys. Res. Solid Earth 89, B3, 1889-1897.

25 Holloway N.H. (1982) North Palawan block, Philippines - Its relation to Asian mainland and role in evolution of South China Sea, Am. Assoc. Pet. Geol. Bull. 66, 9, 1355-1383.

$26 \mathrm{Ru}$ K., Pigott J.D. (1986) Episodic rifting and subsidence in the South China Sea, Am. Assoc. Pet. Geol. Bull. 70, 9, 1136-1155.

27 Taylor B., Hayes D.E. (1983) Origin and history of the South China Sea basin, GMS 27, 23-56.

28 Angelier J. (1994) Fault slip analysis and Paleostress reconstruction, in: Continental deformation, P.L. Hancock (ed), Pergamon Press, Oxford, pp. 53-100.

29 Delvaux D., Sperner B. (2003) New aspects of tectonic stress inversion with reference to the TENSOR program, Geol. Soc. Spec. Publ., London 212, 1, 75-100.

30 Allmendinger R.W., Cardozo N., Fisher D.M. (2012) Structural geology algorithms: Vectors and tensors, Cambridge University Press.

31 Angelier J. (1989) From orientation to magnitudes in paleostress determinations using fault slip data, J. Struct. Geol. 11, 1-2, 37-50.
32 Hyosung Co. Ltd (2018) LPG Underground Storage Project in Mined Rock Cavern in Cai Mep - Geological Investigation Report, Hyosung Co. Ltd.

33 Thuc P.D. (2018) Researching and proposing engineering and technical solutions to improve oil recovery coefficient at the last stage of fractured basement reservoir in White Tiger field. Part II: Evaluation of the effectiveness of maintenance reservoir pressure, exploitation status of each region, existence and causes, Petroleum Magazine, Vietsovpetro.

34 Wyllie D.C., Mah C.W. (2004) Rock slope engineering: Civil and Mining, CRC Press.

35 Allmendinger R.W. (2018) Stereonet 10, accessed 1, 11, 2018.

36 Gzovsky M.V. (1975) Basics of tectonophysics, Science Moscow, p. 535.

37 Sibson R.H. (1985) A note on fault reactivation, J. Struct. Geol. 7, 6, 751-754.

38 King G.C., Stein R.S., Lin J. (1994) Static stress changes and the triggering of earthquakes, Bull. Seismol. Soc. Am. 84, 3, 935-953.

39 Toda S., Stein R.S., Sevilgen V., Lin J. (2011) Coulomb 3.3 Graphic-rich deformation and stress-change software for earthquake, tectonic, and volcano research and teaching - user guide, US Geological Survey Open-File Report 1060, p. 63.

40 Yin Z.M., Ranalli G. (1995) Estimation of the frictional strength of faults from inversion of fault-slip data: a new method, J. Struct. Geol. 17, 9, 1327-1335.

41 Sibson R.H. (2000) Fluid involvement in normal faulting, $J$. Geodyn. 29, 3-5, 469-499.

42 Barton N.C., Choubey V.V. (1976) The shear strength of rock joints in theory and practice, Rock. Mech. Rock. Eng. 10, 1-54.

43 Loc N.L., Linh D.V., Van D.Q., Sang N.T., Tan V.T., Ngoc P.Q., Dien T.N. (2020) Study on recent stress change in the Tuy Hoa - Vung Tau marine region arising from oil and gas exploitation activities, J. Geol. 117-133.

44 Kim T., Zhang N., Jeon S. (2013) A study on shear characteristics of a smooth rock surface under different thermal, hydro and mechanical conditions, in: ISRM International Symposium-EUROCK 2013, International Society for Rock Mech Rock Eng.

45 Dung T.Q., Dung P.T., Ha L.T., Thuan N.V. (2020) Applying geomechanical model and critical stress to identify open fractures in basement reservoir, Petrovietnam J. 3, 30-37. 